объекты утрачивают свое первоначальное назначение или разрушаются, применение приемов историко-культурного зонирования может являться компромиссным способом совершенствования городского пространства. Исторически репрезентативные компоненты городов (промышленные районы, исторические кварталы, улицы и площади, городские парки и скверы, набережные) должны не только описываться в научных трудах и презентоваться в музейных экспозициях, но и становиться частью современной социально-культурной среды.

\section{Список литературы}

1. Агеев И. А. Брендинг города и региона как средство формирования территориальной идентичности: исторический опыт сибирских городов // Вестник науки Сибири. 2015. № 2 (17). C. $155-163$.

2. Гун Г. Е. Концептуальные основы культурной политики для городов // Теория и практика общественного развития. 2014. № 6. C. 265-267.

3. Веденин Ю. А. Базовые принципы культурно-ландшафтного подхода к изучению и сохранению наследия // Наследие и современность. 2020. Т. 3. № 2. С. 7-20.

4. Штеле О.Е. Культурное наследие как основа социально-экономического развития малого исторического города (на примере города Мышкина Ярославской области) // Вестник Московского городского педагогического уни- верситета. Серия: Естественные науки. 2020. № 2 (38). C. 16-27.

5. Колосова И. И., Типтева Д. Н. Исторический центр города в структуре современных городов // Инвестиции, градостроительство, недвижимость как драйверы социальноэкономического развития территории и повышения качества жизни населения: материалы XI Международной конференции. Томск, 2021. C. $310-316$.

6. Насонов А. А., Иванов Е. В. Адаптация культурно-ландшафтного подхода к сохранению наследия и туристскому использованию наследия исторических городов Южной Сибири // Ярослав Мудрый. Проблемы изучения, сохранения и интерпретации историко-культурного наследия: сборник материалов Международной научно-практической конференции. Ярославль, 2018. C. 221-226.

7. Лещенко Н. А. Ревалоризация как реставрационная трансформация для создания качественной городской среды исторического малого города // Вестник Брестского государственного технического университета. 2018. № 1 (109). C. 7-10.

8. Силкина М.Н. Исторические парки и перспективы применения культурноландшафтного подхода к современной городской среде // Кузбасс: образование, наука, инновации: материалы Инновационного конвента. Новокузнецк, 2016. С. 508-512.

Научный руководитель - И. А. Жерносенко, доктор философских наук, доцент Алтайский государственный институт культуры (Россия, Барнаул) irina.jernosenko@gmail.com

\title{
ВЕЛИКАЯ ОТЕЧЕСТВЕННАЯ ВОЙНА В ПРОИЗВЕДЕНИЯХ КОМПОЗИТОРОВ АЛТАЙСКОГО КРАЯ
}

Аннотация. В данной статье рассматриваются произведения алтайских композиторов А. С. Анохина и В. И. Шардакова, посвященные Великой Отечественной войне. Через сохранение и трансляцию нематериального культурного наследия важно популяризировать вокально-хоровое творчество композиторов Алтайского края. Тема Великой Отечественной войны всегда наполнена эмоциями тоски, печали, победной радости и горечи потерь. Сохранение памяти о событиях военных лет не просто важно для будущих поколений. Без этой памяти невозможно построить общество будущего, здоровое духовно и ответственное за свои деяния. Целью данного исследование является 
сохранение памяти о Великой Отечественной войне через популяризацию творчества алтайских композиторов и ревитализацию их наследия.

Ключевые слова: сохранение культурного наследия, композиторы Алтайского края, А. С. Анохин, В. И. Шардаков, Великая Отечественная война, вокально-хоровое творчество, память, популяризачия творчества.

Великая Отечественная война оставила неизгладимый след в истории и памяти русского народа. К сожалению, в последнее время в зарубежной политике, наблюдается устойчивая тенденция к искажению исторических фактов, связанных со Второй мировой войной в целом и ролью СССР в победе над фашизмом, в частности. Несомненно, мы - потомки того времени и героев, защитивших нашу Родину, обязаны сохранить память и передать истинные исторические факты подрастающему поколению. Творческая среда всегда отражает происходящие события, поэтому важно рассматривать культурное наследие в контексте исторических событий. Наследие известных поэтов, композиторов и иных деятелей культуры, оставшееся нам от современников тех трагических событий, оказывает мощное эмоциональное и воспитательное воздействие. Но часть созданных произведений остается неизвестной, поскольку не всегда все было опубликовано и издано своевременно. Культурное наследие Алтайского края невероятно разнообразно и многогранно. Однако большое количество произведений композиторов Алтайского края не опубликованы и хранятся в фондах музеев, в домашних архивах и частных коллекциях.

В процессе изучения рукописей из личного фонда А. С. Анохина Р-1547, хранящегося в Государственном архиве Алтайского края [1], фонда А. В. Анохина из архива Государственного музея истории литературы, искусства и культуры Алтая [2] и частной коллекции Н. И. Шардаковой, были найдены рукописи неизданных произведений композиторов А. С. Анохина и В. И. Шардакова на разные темы. В данной статье хотелось рассмотреть произведения, связанные с тематикой Великой Отечественной войны.

Афанасий Степанович Анохин (02.09.1904 - 18.10.1975) - композитор, педагог, музыкальный деятель Алтая. Свой музыкальный путь он начал в первые годы после революции в хоровой капелле города Бийска. Музыкальное образование он получил в Томском музыкальном техникуме, затем переехал в Барнаул, где занимался педагогической и композиторской деятельностью. В годы Великой Отечественной войны, находясь на фронте, создал несколько песен [3]. Известно, что одна из них была очень популярна среди бойцов - к счастью, сохранилась ее рукопись. Песня на стихи К. Симонова «Жди меня» была написана на Ленинградском фронте 2 января 1943 года [4]. Мелодия, основанная на постепенном движении, пронизана нисходящими секундовыми интонациями, при этом последующие фразы начинаются на новой высоте, что придает драматичность звучанию и приводит к напряженной кульминации, построенной на интонации увеличенной секунды, на словах «Позабыв вчера». Далее происходит спад мелодического напряжения, но при этом эллиптические неразрешенные аккорды не дают расслабиться - это звучит как откровение, а наступающее после постепенное снятие напряжения создает ощущение ожидания и эмоциональной наполненности.

Еще одно интересное произведение А. С. Анохина, созданное в сентябре 1964 года песня «Провожала до вокзала» на слова И. Измайловского [5]. Песня написана в форме миниатюры: начинается как соло и далее включается дуэт, в котором повествуется о проводах в армию солдата любимой девушкой. Мелодия следует за словом, гармония меняется из мажорной окраски лада в минорную - очень изящно и нежно. Обостренно воспринимаются слова кульминации, свидетельствующие о полном принятии ситуации: «От войны храни планету, выше чести нету», что выделяется и тесситурно, и динамически.

Еще одна песня Афанасия Степановича на слова Ф. Карбушева «Подмигнул солдат девчонке» не датирована, имеет несколько игровой характер и наполнена при этом с глубоким смыслом[6]. Маршеобразный аккомпанемент передает обстановку: солдат идет в строю, и подмигнул девчонке, но рядом строгий старшина. Мимолетный сюжет, а сколько скрытого смысла в нем. Подача игровая, шуточная как и сама ситуация является веселой и приятной. Простая трехчастная форма куплета, мелодия следует за словом и комфортно выстроена для исполнения. Прекрасная шуточная песня написана для легкого баритона, передавая образ молодого, озорного солдата.

Тема расставания и тоски звучит в песне «Рябина», на стихи Владимира Герасима. 
Композитор очень чутко подошел к раскрытию образа, передав нежный образ девушки погибшего героя [7]. Витиеватая мелодия передает трепет листвы, минорный лад - печаль и тоску. Три куплета укладывают в себе целую историю о появлении рябины, в которую обратилась девушка, тоскующая о погибшем герое. Очень трогательно звучит мелодия на поддерживающем аккомпанементе. В данной рукописи тщательно прописана агогика (замедление и ускорение темпа, в зависимости от разворачивания сюжета) и нюансировка, что делает исполнение данной песни понятным и выразительным. Данное произведение датировано композитором 10.11.1969 года. Оно свидетельствует о том, что пережитые годы войны, несомненно, оставили неизгладимый след в памяти Афанасия Степановича.

Вершиной военной тематики в творчестве А. С. Анохина является произведение, написанное для смешанного хора a cappella «Солдат не вернулся домой» на слова В. Д. Динабурского. Произведение создано в год кончины композитора - дата на рукописи: март 1975 год [8]. Из представленного списка, это единственное произведение a cappella, обладающее сквозным развитием и детально выстроенной драматургией.

За перелеском поляна.

И там, за поляною той,

В горьком полынном бурьяне -

Могила под старой сосной.

Солдат не вернулся домой.

Стонут над рощею ветры

И зори осенние плачут,

А жить хорошо на свете.

Но в память врывается бой.

Солдат не вернулся домой.

Чувствую я виноватым

Себя перед холмиком тем,

Я тоже, как он был солдатом,

Я шел с ним дорогой одной.

Я шел с ним дорогой одной.

Колышутся травы лесные

Под старой угрюмой сосной.

Помните, люди живые,

Солдат не вернулся домой.

Повторение строк между строфами «Солдат не вернулся домой» звучит в хоре как заклинание памяти, оно ярко выражено динамически и тесситурно. Кульминацию автор вынес на последние строки стихотворения. А предкульминацинный раздел начинается с третьей строфы. Она сначала исполняется мужским составом хора, далее на хоровой педали поочередно подключаются женские голоса, что создает ощущение нарастающего объема и подводит к четвертому четверостишию. В особо значимых моментах композитор использует прием хорового унисона, чтобы подчеркнуть и обратить внимание на текст, так выделяется первая фраза «Солдат не вернулся домой» и предпоследняя строка «Помните, люди живые...», которая является подводящей к кульминации, венчающей всю композицию. Последняя фраза звучит в метроритмическом расширении; ремарка «шире», высокая тесситура голосов и fortissimo создают ощущение крика. Авторы данного произведения помнили и нам завещали хранить память о минувшей войне и погибших на ней соотечественниках.

Еще один композитор, посвятивший военной тематике множество своих произведений и обработок для хора, Василий Иванович Шардаков $(06.02 .1940$ - 14.09.2010 гг.). Его можно назвать учеником Афанасия Степановича Анохина. Как свидетельствуют М. Цурикова и В. Вяземский, «любовь к сочинительству ему привил известный в советские времена алтайский композитор Афанасий Анохин» [9]. Талантливый педагог и хоровой исполнитель, главный хормейстер Театра музыкальной комедии, удивительно чуткий, тонко слышащий хоровую фактуру, и при этом неординарный композитор. Им созданы хоровые миниатюры и баллады на темы любви к женщине, природе, родному краю, а также посвященные теме Великой Отечественной войны. Он не был участником боевых действий, но это не помешало ему создать уникальные произведения для хора, которые входят в репертуар Барнаульского академического хора им. А. Б. Тарнецкого и вызывают яркие эмоции у слушателей. От произведений «Рукавицы», «Не забывайте, люди» при исполнении на концертах всегда возникают у слушателей чувства боли, трепета, тоски и печали, связанные с переживанием событий времен войны.

Произведение «Не забывайте, люди!» на стихи И. Фонякова, невероятно эмоциональное и выразительное.

Поэма в миллионы слов:

Петров, Сергеев, Иванов

Фамилии простые,

Какие слышишь каждый день

В любой, в любом из деревень

И городов России.

Её не складывал поэт

В ней рифмы нет, размера нет,

Но нет и суесловья.

Величественна и трудна

В дни битв и подвигов она

Писалась жаркой кровью. 
В ней ясно слышится меж строк

Гуденье фронтовых дорог,

Рёв танков, гром орудий.

В ней слово каждое болит,

В ней слово каждое велит:

Не забывайте, люди!

Читайте сердцем имена

Пусть каждое сквозь времена

Пройдет и сохранится

Петров, Сергеев, Иванов

Поэма в миллионы слов

Бетонные страницы.

Её не складывал поэт

В ней рифмы нет, размера нет,

Но нет и суесловья.

Величественна и трудна

В дни битв и подвигов она

Писалась жаркой кровью.

В ней ясно слышится меж строк

Гуденье фронтовых дорог,

Рёв танков, гром орудий.

В ней слово каждое болит,

В ней слово каждое велит:

Не забывайте, люди!

В первой части музыка пронизана «звучащими» паузами, передающими ритм разговорной, встревоженной речи. Резкий переход от одноголосия к многоголосию наполнен сдержанной экспрессией, подготавливающей следующую часть. В припеве за счет остинатного октавного удвоения голосов и повторяющейся ритмической формулы короткого пунктира, нарастает напряжение, которое спадает только к третьей части при проведении мужским хором темы из первой части, у женского хора звучит вокализ, строящийся на секундовых, хроматических интонациях, передающих пронзительный «плач». Завершающий припев в окончании переходит в повторение слов «Не забывайте» в виде метро-ритмических изменениях тепо mosso, rubato, ферматы на паузах и над тактовыми чертами, а переход в одноименный фа мажор в окончании производит эффект просветления и создает яркий жизнеутверждающий финал.

Помимо композиторского дара, В. И. Шардаков обладал ярким талантом хорового аранжировщика. Благодаря его аранжировкам произведения других авторов приобретали новые акценты и краски в звучании, обогащались тонкими деталями. Так, широко известное произведение Евгения Мартынова на стихи Андрея Дементьева «Баллада о матери», написанное для сольного исполнения, само по себе вызывает сильные эмоции, но исполнение хоровым коллективом делает его еще ярче. Гармонические краски, наполняющие хоровую фактуру, прони- зывают слушателя щемящей тоской; смена хоровой фактуры с женского хора на смешанный и переход на мужской создает ощущение звучащей картины, реальности происходящего. Диалоги между женской и мужской группой голосов на фразах «Алексей, Алёшенька, сынок», «Алексей, кричали земляки, Алексей, просили, добеги» погружают все глубже в реальность происходящего, и накал страстей не отпускает. А соло сопрано на последних фразах «Дома всё ей чудилось кино, всё ждала вот-вот сейчас в окно, посреди тревожной тишины постучится сын её с войны» звучит на фоне хорового вокализа закрытым ртом - создается впечатление, что в этих словах звучит неизбывная тоска и боль всех матерей, вечно ждущих своих детей с войны. Талантливое сочетание стихов, музыки и хоровой аранжировки сделало данное произведение жемчужиной хоровой музыки.

Тема Великой Отечественной войны не может не трогать сердца и чувства, эта боль воспринимается каждым потомком героического советского народа, защитившего весь мир от большой беды. Задача нашего поколения помнить и передавать это всеми доступными способами, чтобы наши потомки помнили завещание поэтов и композиторов «Не забывайте, люди!»

\section{Список литературы}

1. Личнылй фонд Анохина А. С. // Государственный архив Алтайского края. Ф. Р-1547. Оп. 1.

2. Личный фонд А. В. Анохина // Государственный музей истории литературы, искусства и культуры Алтая.

3. Миненко В. Полвека для музыки. Алтайская правда, 14 сентября 1974 года.

4. Жди меня // Государственный архив Алтайского края. Ф. Р-1547. Оп. 1. Д. 2 - Л. 20.

5. Провожала до вокзала // Государственный архив Алтайского края. Ф. Р-1547. Оп. 1. Д. 14. Л. 26.

6. Подмигнул солдат девчонке // Государственный архив Алтайского края. Ф. Р-1547. ОП. 1. Д. 14. Л. 27.

7. Рябина // Государственный архив Алтайского края. Ф. Р-1547. Оп. 1. Д. 14. Л. 22.

8. Солдат не вернулся домой // Государственный архив Алтайского края. Ф. Р-1547. Оп. 1. Д. 8. Л. 16.

9. Цурикова М., Вязанцеев В. Прошел юбилейный вечер алтайского Моцарта: О творческом вечере главного хормейстера театра музыкальной комедии В. Шардакова // Свободный курс. 2005. 24 февр. (№ 8). 